J. Dairy Sci. 95:3781-3793

http://dx.doi.org/10.3168/jds.2011-5155

(C) American Dairy Science Association ${ }^{\circledR}, 2012$.

\title{
Effect of progesterone on magnitude of the luteinizing hormone surge induced by two different doses of gonadotropin-releasing hormone in lactating dairy cows
}

\author{
J. O. Giordano, P. M. Fricke, J. N. Guenther, G. Lopes Jr., M. M. Herlihy, ${ }^{1}$ A. B. Nascimento, \\ and M. C. Wiltbank ${ }^{2}$ \\ Department of Dairy Science, University of Wisconsin-Madison, Madison 53706
}

\begin{abstract}
Ovulation to the first GnRH injection of Ovsynchtype protocols is lower in cows with high progesterone (P4) concentrations compared with cows with low P4 concentrations, suggesting that $\mathrm{P} 4$ may suppress the release of $\mathrm{LH}$ from the anterior pituitary after $\mathrm{GnRH}$ treatment. The objectives of this study were to determine the effect of 1) circulating $\mathrm{P} 4$ concentrations at the time of GnRH treatment on GnRH-induced LH secretion in lactating dairy cows and 2) increasing the dose of GnRH from 100 to $200 \mu \mathrm{g}$ on LH secretion in a high- and low-P4 environment. A Double-Ovsynch (Pre-Ovsynch: GnRH, PGF $_{2 \alpha} 7$ d later, GnRH 3 d later, and Breeding-Ovsynch 7 d later: $\mathrm{GnRH}, \mathrm{PGF}_{2 \alpha} 7$ d later, and GnRH $48 \mathrm{~h}$ later) synchronization protocol was used to create the high- and low-P4 environments. At the first GnRH injection of Breeding-Ovsynch (high $\mathrm{P} 4$ ), all cows with a corpus luteum $\geq 20 \mathrm{~mm}$ were randomly assigned to receive 100 or $200 \mu \mathrm{g}$ of GnRH. At the second GnRH injection of Breeding-Ovsynch (low $\mathrm{P} 4)$ cows were again randomized to receive 100 or 200 $\mu \mathrm{g}$ of GnRH. Blood samples were collected every 15 min from -15 to 180 min after $\mathrm{GnRH}$ treatment, and then hourly until $6 \mathrm{~h}$ after GnRH treatment. As expected, mean $\mathrm{P} 4$ concentrations were greater for cows in the high- than the low-P4 environment. For cows receiving $100 \mu \mathrm{g}$ of $\mathrm{GnRH}$, the $\mathrm{LH}$ peak and area under the curve (AUC) were greater in the low- than in the high-P4 environment. Similarly, for cows receiving 200 $\mu \mathrm{g}$ of $\mathrm{GnRH}$, the LH peak and AUC were greater in the low- than the high-P4 environment. Cows receiving 100 or $200 \mu \mathrm{g}$ of $\mathrm{GnRH}$ had greater mean LH concentration in the low- than the high-P4 environment from 1 to $6 \mathrm{~h}$ after GnRH treatment. On the other hand, when comparing the effect of the $2 \mathrm{GnRH}$ doses in the high- and
\end{abstract}

Received November 16, 2011.

Accepted February 8, 2012.

${ }^{1}$ Current address: Teagasc, Animal and Grassland Research and Innovation Centre, Moorepark, Fermoy, Co. Cork, Ireland.

${ }^{2}$ Corresponding author: wiltbank@wisc.edu
low-P4 environments, cows receiving $200 \mu \mathrm{g}$ of $\mathrm{GnRH}$ had a greater LH peak and AUC than cows treated with $100 \mu \mathrm{g}$ of GnRH both in the high- and low-P4 environments. For the high-P4 environment, mean LH was greater from 1.5 to $5 \mathrm{~h}$ after GnRH treatment for cows receiving $200 \mu \mathrm{g}$ of $\mathrm{GnRH}$ than for those receiving $100 \mu \mathrm{g}$ of GnRH. In the low-P4 environment, mean $\mathrm{LH}$ was greater for cows receiving $200 \mu \mathrm{g}$ of $\mathrm{GnRH}$ than for those receiving $100 \mu \mathrm{g}$ of $\mathrm{GnRH}$ from 1 to $2.5 \mathrm{~h}$ after $\mathrm{GnRH}$ treatment. We conclude that the P4 environment at $\mathrm{GnRH}$ treatment dramatically affects GnRH-induced LH secretion, and that a 200- $\mu$ g dose of GnRH can increase LH secretion in either a high- or a low-P4 environment.

Key words: luteinizing hormone secretion, progesterone, gonadotropin-releasing hormone dose

\section{INTRODUCTION}

The Ovsynch protocol uses $\mathrm{GnRH}$ and $\mathrm{PGF}_{2 \alpha}$ to manipulate follicular and luteal function to synchronize ovulation of a follicle and allow for timed AI (TAI; Pursley et al., 1995). Ovulatory response to both GnRH injections of the Ovsynch protocol improves overall synchronization of ovulation and subsequent fertility of TAI services in lactating dairy cows (Chebel et al., 2006; Keskin et al., 2011; Giordano et al., 2012). Ovulation to the first GnRH injection of the Ovsynch protocol is lower in cows that have high circulating progesterone (P4) concentrations, indicative of the presence of a functional corpus luteum (CL), or in cows with a CL detected using ultrasound compared with cows with low P4 or without a CL (Stevenson et al., 2008; Galvão and Santos, 2010; Giordano et al., 2012). Interestingly, in experiments in which cows were presynchronized using 2 injections of $\mathrm{PGF}_{2 \alpha}$, the presence of a follicle of ovulatory size at the first GnRH injection of Ovsynch does not appear to be the limitation for ovulation to $\mathrm{GnRH}$ because most cows have a follicle of ovulatory size at the time of GnRH treatment (Galvão and Santos, 2010). Therefore, it seems likely that the suppression of ovulation observed in cows with a func- 
tional CL treated with $\mathrm{GnRH}$ is related to alterations in the mechanisms that trigger the ovulatory process rather than the capacity of follicles to ovulate.

In ruminants, P4 and estradiol play a major role in regulating $\mathrm{LH}$ secretion from the anterior pituitary (Goodman and Karsch, 1980; Schoenemann et al., 1985; Nett et al., 2002). Steroids can modulate LH release through indirect mechanisms that regulate hypothalamic GnRH secretion or directly on the pituitary through enhancement or suppression of pituitary response to GnRH (Schoenemann et al., 1985; Baratta et al., 1994; Rispoli and Nett, 2005). During the preovulatory period, an increase in estradiol from the preovulatory follicle increases the sensitivity of the anterior pituitary to $\mathrm{GnRH}$ by upregulating GnRH receptor mRNA and protein in gonadotrophs (Schoenemann et al., 1985). In addition, estradiol enhances hypothalamic GnRH secretion, eventually leading to the preovulatory $\mathrm{GnRH}$ surge, which triggers the LH surge. Conversely, in the presence of a functional CL, P4 blocks the stimulatory effects of estradiol-17 $\beta$ (E2) at the hypothalamus (Schoenemann et al., 1985; Girmus and Wise, 1992) and possibly at the anterior pituitary (Baratta et al., 1994; Rispoli and Nett, 2005).

Studies using beef heifers and cows support the hypothesis that the magnitude of the GnRH-induced LH surge in cattle depends on the $\mathrm{P} 4$ environment at GnRH treatment (Colazo et al., 2008; Dias et al., 2010). A limitation of these studies, however, was that cattle in the low-P4 groups had mean P4 concentrations greater than $1 \mathrm{ng} / \mathrm{mL}$ [presence of a controlled internal drug release (CIDR) insert or CL in all treatments], a $\mathrm{P} 4$ concentration indicative of a functional CL, and a level of circulating P4 that may already be inhibitory to GnRH-induced LH secretion. In contrast, Zolman et al. (1974) reported no differences in LH peak concentrations in response to $\mathrm{GnRH}$ treatment in Holstein heifers on either d 15 or 20 of the estrous cycle when P4 concentrations averaged 3.9 and $0.4 \mathrm{ng} /$ $\mathrm{mL}$, respectively. Unfortunately, only $\mathrm{LH}$ peak concentrations were reported, a value that does not provide complete information on total GnRH-induced LH secretion. Thus, additional studies are necessary to directly compare the effect of $\mathrm{P} 4$ on the magnitude of the $\mathrm{LH}$ surge in high- and low-P4 environments. In addition to the biological importance of this research area, our major interest was to compare the $\mathrm{GnRH}$ response during experimental conditions that replicate the physiological environments observed during synchronization of ovulation using an Ovsynch protocol in lactating dairy cows. During the Ovsynch protocol, cows have relatively high P4 concentration $(\geq 1 \mathrm{ng} / \mathrm{mL})$ at the time of the first GnRH injection (Stevenson et al., 1999; Bello et al.,
2006; Giordano et al., 2012), whereas P4 concentration is usually low (usually below $0.5 \mathrm{ng} / \mathrm{mL}$ ) at the second GnRH injection (Stevenson et al., 2008; Brusveen et al., 2009; Giordano et al., 2012).

A potential strategy to enhance $\mathrm{GnRH}$-induced $\mathrm{LH}$ release in lactating dairy cows may be to increase the dose of GnRH administered. Studies in cattle have reported diverse results using different doses of GnRH with either enhanced or similar LH release in response to increasing doses of GnRH (Chenault et al., 1990; Yamada et al., 2002; Colazo et al., 2009; Rantala et al., 2009; Souza et al., 2009; Dias et al., 2010). Much of the variation in these results may be attributed to factors associated with the experimental design of these studies, including the type and physiological conditions of the animals used, variations among $\mathrm{GnRH}$ products, GnRH doses administered, LH assay methods, parameters used to compare LH secretion, and the steroid milieu at the time of GnRH treatment. From a biological perspective, increased doses of GnRH can provide an indication of whether changes in GnRH-induced LH responses are due to lack of sufficient pituitary LH content. From a practical point of view, increasing the GnRH dose could be a simple method to enhance LH secretion during Ovsynch-type protocols, potentially resulting in enhanced ovulation and increased synchronization to the protocol. Because Ovsynch-type protocols are currently used extensively in the dairy industry (Caraviello et al., 2006; Olynk and Wolf, 2008; Norman et al., 2009), we performed this experiment to assess the effect of $\mathrm{P} 4$ concentration and 2 different doses of GnRH during the 2 time points that $\mathrm{GnRH}$ is administered during an Ovsynch protocol.

The objectives of this study were to determine the effect of 1) circulating $\mathrm{P} 4$ concentrations at the time of $\mathrm{GnRH}$ treatment on GnRH-induced LH secretion in lactating dairy cows and 2) increasing the dose of GnRH from 100 to $200 \mu \mathrm{g}$ on LH secretion in a highand low-P4 environment. The specific hypotheses of this experiment were that a high-P4 environment would suppress LH secretion in response to exogenous $\mathrm{GnRH}$ treatment and further, that a higher dose of exogenous GnRH would result in greater LH secretion in both a high- and a low-P4 environment.

\section{MATERIALS AND METHODS}

This experiment was conducted from November 2009 to December 2009 using cows in the University of Wisconsin-Madison dairy herd. All procedures were approved by the Animal Care and Use Committee for the College of Agriculture and Life Sciences of the University of Wisconsin-Madison. 


\section{Cows}

Lactating primiparous $(\mathrm{n}=5)$ and multiparous ( $\mathrm{n}$ $=19)$ Holstein $(\mathrm{n}=17)$ and crossbred $(\mathrm{n}=7 ; 3 / 4$ Holstein, 1/4 Jersey) dairy cows were used for this experiment. During the presynchronization part of the experiment, cows were housed in freestall barns at the Blaine Dairy Cattle Center (Arlington, WI), whereas during the intensive part of the experiment when treatments where administered, cows were housed in a tiestall barn at the Dairy Cattle Teaching and Research Center at the University of Wisconsin-Madison. During both study periods, cows were fed a TMR diet once daily with ad libitum access to feed and water. The diet was formulated to meet or exceed NRC requirements (NRC, 2001) for high-producing lactating dairy cows. Throughout the experiment, cows were milked twice daily at approximately 12 -h intervals, and all cows received s.c. injections of bovine somatotropin (Posilac, $500 \mathrm{mg}$; Elanco Animal Health, Indianapolis, IN) at 14-d intervals beginning $63 \pm 3 \mathrm{~d}$ postpartum.

\section{Treatments}

High- and low-P4 environments in this experiment were evaluated by enrolling cows in the Double-Ovsynch protocol (Pre-Ovsynch: GnRH, $\mathrm{PGF}_{2 \alpha} 7$ d later, GnRH 3 d later, and Breeding-Ovsynch 7 d later: GnRH, $\mathrm{PGF}_{2 \alpha} 7 \mathrm{~d}$ later, and GnRH $48 \mathrm{~h}$ later; Souza et al.,
2008) with minor modifications (48 instead of $56 \mathrm{~h}$ between $\mathrm{PGF}_{2 \alpha}$ and second GnRH in Breeding-Ovsynch). Cows at various DIM and AI services completed the Pre-Ovsynch portion of the Double-Ovsynch protocol to induce an ovulation and formation of a CL to generate the high-P4 environment at the first $\mathrm{GnRH}$ injection of Breeding-Ovsynch. The time of the first GnRH injection of the Breeding-Ovsynch will be referred to as the high-P4 environment (high P4). Seven days after the GnRH injection, cows received a luteolytic dose of $\mathrm{PGF}_{2 \alpha}(500 \mu \mathrm{g}$ of Estrumate, $250 \mu \mathrm{g} / \mathrm{mL}$ of cloprostenol sodium; Schering-Plough Animal Health, Summit, NJ) to induce luteal regression and generate the low-P4 environment (low $\mathrm{P} 4$ ) to receive the second GnRH injection of Breeding-Ovsynch. At the time of GnRH treatment in both the high- and low-P4 environments, cows $(\mathrm{n}=24)$ were paired by lactation number and DIM and were randomly assigned to receive either $100(\mathrm{n}=12)$ or $200(\mathrm{n}=12) \mu \mathrm{g}$ of GnRH (Fertagyl, 50 $\mu \mathrm{g} / \mathrm{mL}$ of gonadorelin diacetate tetrahydrate; Intervet Animal Health, Millsboro, DE; Figure 1).

\section{Ultrasound Examinations for Determination of Ovulatory Response to GnRH}

To determine ovulation after the second GnRH injection of Pre-Ovsynch and ensure the presence of a functional CL at the first GnRH injection of Breeding-

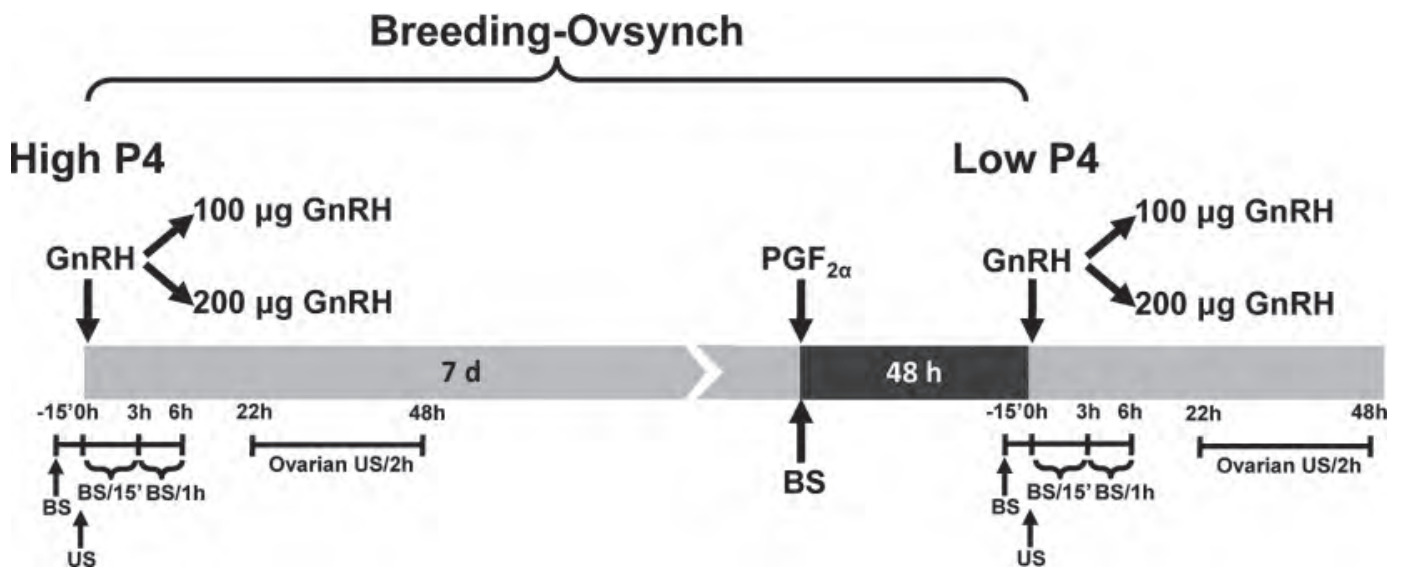

Figure 1. Schematic representation of experimental procedures. Cows were enrolled in a Double-Ovsynch protocol (DO; Pre-Ovsynch: GnRH, $\mathrm{PGF}_{2 \alpha} 7 \mathrm{~d}$ later, GnRH 3 d later, and Breeding-Ovsynch 7 d later: GnRH, PGF $_{2 \alpha} 7$ d later, and GnRH $48 \mathrm{~h}$ later) to generate high- and low-progesterone (P4) environments. Only cows with confirmed ovulation within 30 to $32 \mathrm{~h}$ after the second GnRH injection of Pre-Ovsynch (not shown) and a functional corpus luteum (CL) immediately before the first GnRH injection of Breeding-Ovsynch initiated $(\mathrm{n}=24)$ the experiment. Within each P4 environment, cows were paired by lactation number and DIM and were randomly assigned to receive either 100 or 200 $\mu \mathrm{g}$ of $\mathrm{GnRH}$. Blood samples (BS) were collected to measure circulating LH concentrations from -15 min to $6 \mathrm{~h}$ after GnRH treatment in both the high- and low-P4 environments. During the first $3 \mathrm{~h}$ and $15 \mathrm{~min}$ of the blood sampling period, samples were collected every 15 min and then every $1 \mathrm{~h}$ from 3 to $6 \mathrm{~h}$ after $\mathrm{GnRH}$ treatment. Blood samples were also collected at the first $\mathrm{GnRH}$ injection, $\mathrm{PGF}_{2 \alpha}$ injection, $48 \mathrm{~h}$ after the $\mathrm{PGF}_{2 \alpha}$ injection, and $8 \mathrm{~d}$ after the second GnRH injection (not shown) of the Breeding-Ovsynch portion of DO to measure P4 concentrations. Ovarian ultrasonography (US) was performed after GnRH treatment to assess ovulatory response to GnRH treatment in the high- and low-P4 environments. Ovarian US was performed at GnRH treatment and then every $2 \mathrm{~h}$ beginning $22 \mathrm{~h}$ after GnRH treatment until ovulation or $48 \mathrm{~h}$ after GnRH treatment, whichever occurred first. 
Ovsynch, transrectal ultrasonography (US) of the ovaries was performed in all cows enrolled to record the location and diameter of follicles present. Ovulation in response to GnRH treatment was defined as the disappearance of one or more follicles present on the ovaries within 30 to $32 \mathrm{~h}$ after the $\mathrm{GnRH}$ injection. Seven days after the second GnRH injection of Pre-Ovsynch, cows that presented an ovulation were evaluated using US to confirm the presence of a CL and only those cows having at least $1 \mathrm{CL}$ with a diameter $\geq 20 \mathrm{~mm}$ continued in the study to receive the first $\mathrm{GnRH}$ injection of Breeding-Ovsynch $(\mathrm{n}=24)$. Throughout this part of the experiment, all US examinations were performed using a portable ultrasound scanner (Easi-Scan; BCF Technology Ltd., Livingston, UK) fitted with a 7.5$\mathrm{MHz}$ linear array transducer.

Ovulatory responses after $\mathrm{GnRH}$ treatment in highand low-P4 environments were determined as described previously for the presynchronization period. At this time, however, an Aloka 500V (Corometrics Medical Systems Inc., Wallingford, CT) ultrasound machine equipped with a transrectal $7.5-\mathrm{MHz}$ linear-array transducer was used to perform the examinations. During all US sessions, all CL and antral follicles $\geq 8 \mathrm{~mm}$ present on the ovaries were mapped. For each ovarian structure, 2 diameter measurements, taken at right angles, were recorded on a single image of the apparent maximal diameter of the structure using the digital calipers of the ultrasound machine, and diameters were calculated as the mean of these 2 measurements. Ovarian US sessions were performed at the time of $\mathrm{GnRH}$ treatment and then every $2 \mathrm{~h}$ starting $22 \mathrm{~h}$ after $\mathrm{GnRH}$ treatment until ovulation occurred or $48 \mathrm{~h}$ after $\mathrm{GnRH}$ treatment, whichever occurred first (Figure 1). Ovarian US was performed again $7 \mathrm{~d}$ after $\mathrm{GnRH}$ treatment in the high$\mathrm{P} 4$ environment and $8 \mathrm{~d}$ after $\mathrm{GnRH}$ treatment in the low-P4 environment to confirm ovulation.

\section{Blood Sample Collection}

Blood samples were collected via puncture of the median caudal vein or artery with $8-\mathrm{mL}$ evacuated tubes (Vacutainer; Becton, Dickinson and Co., Franklin Lakes, NJ) to determine P4 concentrations before GnRH treatment in both the high- and low-P4 environments to confirm that cows had high or low P4 concentrations (cutoff $1 \mathrm{ng} / \mathrm{mL}$ ), respectively (Figure 1). Blood samples were then collected in the same manner at the time of and $48 \mathrm{~h}$ after the $\mathrm{PGF}_{2 \alpha}$ injection given $7 \mathrm{~d}$ after $\mathrm{GnRH}$ treatment in the high-P4 environment to confirm luteal regression (Figure 1). Finally, blood samples for determination of $\mathrm{P} 4$ were collected $8 \mathrm{~d}$ after $\mathrm{GnRH}$ treatment in the low-P4 environment to confirm ovulation.
For determination of LH concentration, blood samples were collected from the jugular vein using Monovette tubes (Sarstedt Inc., Newton, NC) attached to indwelling jugular catheters. Samples were collected every 15 min for $3 \mathrm{~h}$ and 15 min starting 15 min before GnRH treatment and then every hour for 3 additional h (total sampling period: $6 \mathrm{~h}$ and $15 \mathrm{~min}$ ) in both the high-P4 and low-P4 environments (Figure 1).

After collection, blood samples were immediately placed on ice for at least $30 \mathrm{~min}$, then removed from the ice for approximately $30 \mathrm{~min}$, and centrifuged $(2,000$ $\times g)$ at $4^{\circ} \mathrm{C}$ for $25 \mathrm{~min}$. After centrifugation, serum was collected and stored at $-20^{\circ} \mathrm{C}$ in 5 -mL scintillation vials until assayed.

\section{P4 and LH Assays}

Progesterone concentrations were determined in duplicate using a commercial solid-phase, no-extraction RIA (Coat-a-count; Diagnostic Products Corp., Los Angeles, CA). To assess the precision of the assay, control samples with a high $(18 \mathrm{ng} / \mathrm{mL})$ and low $(0.5 \mathrm{ng} /$ $\mathrm{mL}$ ) concentration of $\mathrm{P} 4$ were assayed. Average sensitivity for the $\mathrm{P} 4$ assay was $0.005 \mathrm{ng} / \mathrm{mL}$. The average intraassay coefficient of variation for the high-concentration serum sample was $1.4 \%$, whereas the coefficient of variation was $5.9 \%$ for the low-concentration sample.

Luteinizing hormone concentrations were determined in duplicate samples by RIA as described in Palhao et al. (2009) and modified as described by Hannan et al. (2010). The standard curve ranged from 0.08 to $10 \mathrm{ng} / \mathrm{mL}$ of LH. Therefore, samples with percentage binding less than $10 \%$ due to high LH concentrations were diluted either 1:4 or 1:20 and reanalyzed to obtain percentage binding in the 30 to $60 \%$ range, which corresponded to 1.25 and $0.625 \mathrm{ng} / \mathrm{mL}$ standards. To assess the precision of the 5 separate LH assays run, control samples with a low $(0.3 \mathrm{ng} / \mathrm{mL})$ and high $(1.3 \mathrm{ng} / \mathrm{mL})$ concentration of LH were evaluated in each assay. The average sensitivity of the assays was $0.12 \mathrm{ng} / \mathrm{mL}$. For the low sample, the average intraassay coefficient of variation was $5.5 \%$ (range $=1.34$ to 9.09 ), whereas the interassay coefficient of variation was $7.5 \%$. For the high-LH sample, the average intraassay coefficient of variation was $3.2 \%$ (range $=1.45$ to 4.30 ) and the interassay coefficient of variation was $5.8 \%$.

\section{Statistical Analyses}

Separate statistical analyses were performed to test the first hypothesis of the effect of $\mathrm{P} 4$ environment on GnRH-induced LH response and then to test the second hypothesis of the effect of GnRH dose on LH secretion in both high- and low-P4 environments. Before 
statistical analyses, normality of the data set for the different variables under consideration $[\mathrm{P} 4$ at $\mathrm{GnRH}$, LH peak concentration, time to LH peak, area under the curve (AUC), mean LH concentration, and time to ovulation] was tested using the Shapiro-Wilk statistic and graphical methods (Q-Q plot, probability plot, and histogram) obtained with PROC UNIVARIATE of SAS 9.2 (SAS Institute Inc., Cary, NC). When nonnormality of the data was detected, the variables under consideration were transformed accordingly through natural $\log$, square root, or power transformation to ensure normality of the data distribution. For variables in which it was not possible to achieve normality of the data distribution through the previously mentioned transformations, nonparametric analysis for ranked transformed data was performed with the Wilcoxon 2-sample test using the NPAR1WAY procedure of SAS. For this analysis, the classification variables were either $\mathrm{P} 4$ environment or $\mathrm{GnRH}$ dose. For all variables presenting a normal distribution before or after transformations, the effects of $\mathrm{P} 4$ environment and $\mathrm{GnRH}$ dose on the height of the LH peak, time to the LH peak, and AUC (approximated with the trapezoidal method and reported as arbitrary units) were analyzed by ANOVA with PROC MIXED of SAS. Differences in P4 concentration in the high- and low-P4 environments and for cows receiving 100 versus $200 \mu \mathrm{g}$ of $\mathrm{GnRH}$ were tested similar to the variables associated with the LH response. All original models contained P4 environment (high vs. low) or GnRH dose (100 vs. $200 \mu \mathrm{g}$ of $\mathrm{GnRH}$ ), parity (primiparous vs. multiparous), and BCS (high $\geq 2.5$ vs. low $<2.5$ ) as classificatory variables, whereas DIM and BW were used as covariates in the model. After running the original models containing all explanatory variables and covariates for each one of the outcome variables under consideration, model selection was performed by backward elimination of those variables with a $P$-value $>0.10$. In addition, model selection was performed by selecting the model with the lowest value for the Akaike information criterion.

Analysis of differences in mean LH concentration after GnRH treatment was performed using ANOVA with repeated measures with PROC MIXED of SAS. According to the specific analysis being performed, the model contained the fixed effects of $\mathrm{P} 4$ environment or GnRH dose, time, and the P4 environment or GnRH dose by time interaction. Parity and BCS were also included as explanatory variables, whereas DIM and BW were included as covariates. Cow within P4 environment or GnRH dose was used as a random effect in the model and was the subject of repeated measures analysis using a spatial power covariance structure to adjust for the nonuniform blood collection time intervals $(15 \mathrm{~min}$ for the first $3 \mathrm{~h}$ after treatment and then every $1 \mathrm{~h}$ until the end of the sampling period). The Kenward-Rogers method was used for the degrees of freedom calculation. Model selection was performed as described previously. Finally, ovulatory response by P4 environment and GnRH dose was analyzed with logistic regression using the PROC GLIMMIX of SAS with a model that contained $\mathrm{P} 4$ environment or $\mathrm{GnRH}$ dose treatment as explanatory variables.

A significant difference between the levels of a classificatory variable or a covariate was considered when $P<0.05$, whereas differences between $P \geq 0.05$ and $P$ $\leq 0.10$ were considered a statistical tendency. Further analysis of differences between least squares means was performed with the Tukey-Kramer post hoc mean separation test. For clarity of interpretation data are presented as arithmetic means \pm standard error of the means.

\section{RESULTS}

\section{Effect of P4 on LH Secretion}

For cows receiving $100 \mu \mathrm{g}$ of $\mathrm{GnRH}$, the mean P4 concentration was greater $(P<0.001)$ in the high-P4 than in the low-P4 environment (Table 1). Peak LH concentrations after treatment with $100 \mu \mathrm{g}$ of $\mathrm{GnRH}$ were greater $(P<0.001)$, whereas time to the $\mathrm{LH}$ peak tended $(P=0.075)$ to be greater for cows in the lowthan for cows in the high-P4 environment (Table 1). In addition, the AUC was greater $(P<0.001)$ for cows in the low- than for cows in the high-P4 environment (Table 1).

Mean LH concentrations throughout the sampling period after treatment with $100 \mu \mathrm{g}$ of $\mathrm{GnRH}$ (Figure $2 \mathrm{~A})$ were affected by $\mathrm{P} 4$ concentration $(P<0.001)$, time $(P<0.001)$, and the $\mathrm{P} 4$ concentration by time interaction $(P<0.001)$. In the high-P4 environment, the $100 \mu \mathrm{g}$ dose of GnRH did not increase mean LH concentrations beyond $5 \mathrm{ng} / \mathrm{mL}$ at any time after GnRH treatment. For cows treated with GnRH in the low-P4 environment, mean LH was greater than $5 \mathrm{ng} /$ $\mathrm{mL}$ at all times from 0.75 until $3 \mathrm{~h}$ after $\mathrm{GnRH}$ treatment and was greater than $10 \mathrm{ng} / \mathrm{mL}$ from 1.5 to $2.5 \mathrm{~h}$ after $\mathrm{GnRH}$ treatment. Mean LH concentrations were greater in the low- than the high-P4 environment from 1 to $6 \mathrm{~h}$ after GnRH treatment with more than 2-fold greater LH concentrations at all of these times and 5 -fold greater differences from 1.75 to $5 \mathrm{~h}$ after $\mathrm{GnRH}$ treatment.

Ovulatory response to GnRH treatment was recorded, although this study was not designed to validly analyze treatment effects on this binomial response. For cows receiving $100 \mu \mathrm{g}$ of $\mathrm{GnRH}, 1$ cow treated in the low-P4 environment was eliminated because the only 
Table 1. Effect of progesterone concentration at GnRH treatment on LH secretion in lactating dairy cows receiving 100 or $200 \mu \mathrm{g}$ of $\mathrm{GnRH}{ }^{1}$

\begin{tabular}{|c|c|c|c|c|c|c|}
\hline Item & \multicolumn{2}{|c|}{$100 \mu \mathrm{g}$ of $\mathrm{GnRH}$} & $P$-value & \multicolumn{2}{|c|}{$200 \mu \mathrm{g}$ of $\mathrm{GnRH}$} & $P$-value \\
\hline Progesterone (ng/mL) & $\begin{array}{l}3.5 \pm 0.2 \\
\quad(2.2-4.8)\end{array}$ & $\begin{array}{l}0.2 \pm 0.05 \\
\quad(0.1-0.6)\end{array}$ & $<0.001$ & $\begin{array}{l}3.6 \pm 0.4 \\
\quad(1.1-5.3)\end{array}$ & $\begin{array}{l}0.2 \pm 0.02 \\
\quad(0.1-0.4)\end{array}$ & $<0.001$ \\
\hline LH peak $(\mathrm{ng} / \mathrm{mL})$ & $3.3 \pm 0.3$ & $15.7 \pm 2.2$ & $<0.001$ & $8.5 \pm 1.7$ & $23.6 \pm 1.6$ & 0.001 \\
\hline Time to LH peak $(\mathrm{h})$ & $1.3 \pm 0.2$ & $1.8 \pm 0.1$ & 0.075 & $1.8 \pm 0.2$ & $1.9 \pm 0.1$ & 0.850 \\
\hline $\mathrm{AUC}^{2}$ (units) & $501.0 \pm 42.6$ & $2,186.4 \pm 279.7$ & $<0.001$ & $1,177.8 \pm 193.3$ & $3,443.2 \pm 198.1$ & 0.001 \\
\hline
\end{tabular}

${ }^{1}$ All values are means \pm SEM; for progesterone, range in parentheses.

${ }^{2}$ Area under the curve.
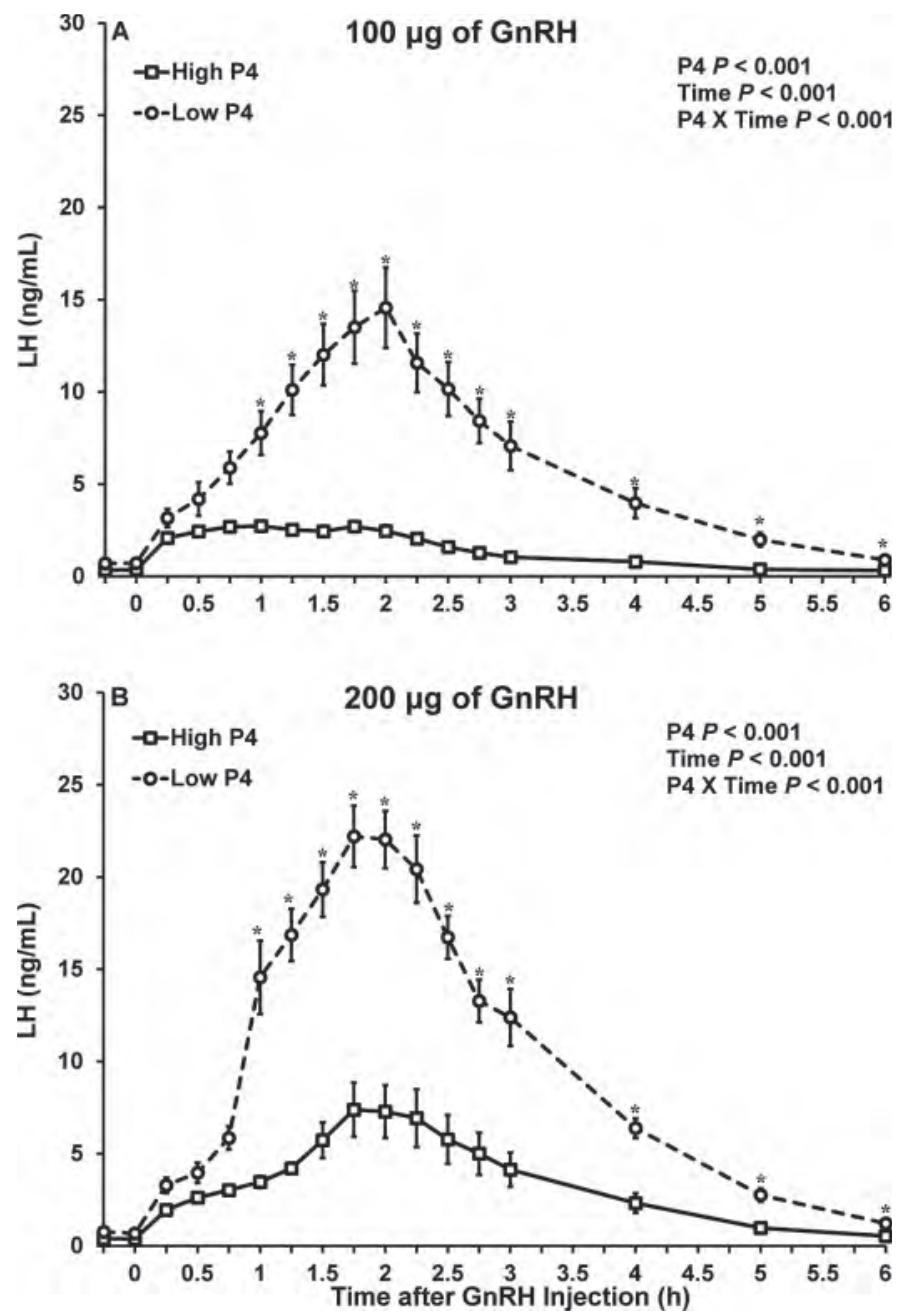

Figure 2. Mean ( \pm SEM) LH concentrations in lactating dairy cows treated with $100 \mu \mathrm{g}$ [panel A; high-progesterone (P4) environment (n $=12)$ and low-P4 environment $(\mathrm{n}=12)$ ] or $200 \mu \mathrm{g}$ of $\mathrm{GnRH}$ [panel B; high-P4 environment $(\mathrm{n}=12)$ and low-P4 environment $(\mathrm{n}=10)]$ in a high- versus a low-P4 environment at the first and second GnRH injections of the Breeding-Ovsynch portion of the Double-Ovsynch protocol, respectively. Asterisks denote a difference (Tukey mean separation test) in mean LH concentration between groups of cows. follicle of ovulatory size $(\geq 10 \mathrm{~mm})$ ruptured during the US examination at $\mathrm{GnRH}$ treatment. After elimination of this cow, ovulatory response to the $100-\mu \mathrm{g}$ dose of GnRH was similar $(P=0.344)$ for cows in the high-P4 $(75.0 \%, 9 / 12)$ and the low-P4 $(90.9 \%, 10 / 11)$ environments. The mean diameter of the largest follicle of cows in the high-P4 environment was $16.9 \mathrm{~mm}$ (range $=14$ to $21 \mathrm{~mm}$ ), whereas it was $17.7 \mathrm{~mm}$ (range $=14$ to 24 $\mathrm{mm}$ ) for cows in the low-P4 environment. The diameter of the largest follicle of the 4 cows failing to ovulate in response to $\mathrm{GnRH}$ treatment was $17,18,18$, and 21 $\mathrm{mm}$. The mean time from $\mathrm{GnRH}$ treatment to ovulation was similar $(P=0.256)$ for cows receiving the low dose of GnRH both in the high-P4 $(29.3 \pm 0.5 \mathrm{~h}$; range 28 to $32 \mathrm{~h})$ and the low-P4 $(28.6 \pm 0.3 \mathrm{~h}$; range 28 to $30 \mathrm{~h}$ ) environments.

Data from 2 cows receiving $200 \mu \mathrm{g}$ of $\mathrm{GnRH}$ were eliminated from the data set because they had 1.4 and $2.4 \mathrm{ng} / \mathrm{mL}$ of circulating $\mathrm{P} 4$ at $\mathrm{GnRH}$ treatment in the low-P4 environment, indicating lack of complete luteal regression to the $\mathrm{PGF}_{2 \alpha}$ injection given $2 \mathrm{~d}$ earlier. For cows receiving $200 \mu \mathrm{g}$ of $\mathrm{GnRH}$, the mean concentration of $\mathrm{P} 4$ was greater $(P<0.001)$ in the high- than in the low-P4 environment (Table 1). The peak LH concentration after treatment with $200 \mu \mathrm{g}$ of $\mathrm{GnRH}$ was greater $(P=0.001)$, whereas time to the LH peak was similar $(P=0.850)$ for cows with low $\mathrm{P} 4$ compared with cows with high $\mathrm{P} 4$ concentrations (Table 1). In addition, the AUC was greater $(P=0.001)$ for cows with low $\mathrm{P} 4$ than for cows with high $\mathrm{P} 4$ concentrations (Table 1).

Mean LH concentrations throughout the sampling period after treatment with $200 \mu \mathrm{g}$ of $\mathrm{GnRH}$ were also affected by the $\mathrm{P} 4$ environment $(P<0.001)$, time $(P<$ $0.001)$, and the $\mathrm{P} 4$ environment by time interaction $(P$ $<0.001$; Figure 2B). Unlike cows treated with $100 \mu \mathrm{g}$ of GnRH in the high-P4 environment, cows receiving 200 $\mu \mathrm{g}$ of GnRH reached mean circulating LH concentrations greater than $5 \mathrm{ng} / \mathrm{mL}$ during the maximum secretion period from 1.5 to $2.5 \mathrm{~h}$ after $\mathrm{GnRH}$ treatment. However, LH concentrations were less than $10 \mathrm{ng} / \mathrm{mL}$ at all times for cows receiving $200 \mu \mathrm{g}$ of GnRH in a high- 
P4 environment. By contrast, the pattern of circulating $\mathrm{LH}$ concentrations in cows receiving $200 \mu \mathrm{g} \mathrm{GnRH}$ was quite distinct with slowly increasing LH concentrations during the first $30 \mathrm{~min}$ and then a dramatic increase in $\mathrm{LH}$ concentrations between $45 \mathrm{~min}$ and $1 \mathrm{~h}$ after $\mathrm{GnRH}$ treatment. Circulating LH concentrations remained high from 1 to $3 \mathrm{~h}$ after GnRH treatment in cows with low $\mathrm{P} 4$, exceeding concentrations of $20 \mathrm{ng} / \mathrm{mL}$ during this interval. Mean LH concentrations were greater for cows in the low-P4 environment than the high-P4 environment from 1 to $6 \mathrm{~h}$ after $\mathrm{GnRH}$ treatment, with more than 3 -fold greater LH concentrations from 1 to 2 $\mathrm{h}$ after treatment and 2-fold greater LH concentrations until the end of the sampling period.

Finally, ovulatory responses of cows receiving 200 $\mu \mathrm{g}$ of $\mathrm{GnRH}$ were similar $(P=0.979)$ for cows in the high-P4 (91.7\%, 11/12) and the low-P4 (100\%, 10/10) environments. The mean diameter of the largest follicle of cows in the high-P4 environment was $16.7 \mathrm{~mm}$ (range $=14$ to $21 \mathrm{~mm}$ ), whereas it was $16.0 \mathrm{~mm}$ (range $=12$ to $21 \mathrm{~mm}$ ) for cows in the low-P4 environment. The diameter of the largest follicle of the only cow failing to ovulate after GnRH treatment was $16 \mathrm{~mm}$. At the last US examination, the follicle did not appear to have ruptured; however, $\mathrm{P} 4$ concentrations were 1.9 $\mathrm{ng} / \mathrm{mL} 8 \mathrm{~d}$ later. The time from $\mathrm{GnRH}$ treatment to ovulation was similar $(P=0.549)$ for cows receiving $200 \mu \mathrm{g}$ of $\mathrm{GnRH}$ both in the high- $(29.1 \pm 0.3 \mathrm{~h}$, range 28 to $30 \mathrm{~h})$ and the low- $(28.8 \pm 0.3 \mathrm{~h}$, range 28 to 30 h) P4 environments.

\section{Effect of GnRH Dose on LH Secretion}

All cows in the high-P4 environment had P4 >1.0 $\mathrm{ng} / \mathrm{mL}$ at $\mathrm{GnRH}$ treatment. Progesterone concentrations were similar $(P=0.806)$ for cows in the 100 and $200-\mu \mathrm{g}$ GnRH treatments (Table 2).

Cows receiving $200 \mu \mathrm{g}$ of $\mathrm{GnRH}$ had a greater $\mathrm{LH}$ peak $(P<0.001)$ and a shorter $(P=0.040)$ time to the LH peak than cows receiving $100 \mu \mathrm{g}$ of GnRH (Table 2). For LH peak concentration, DIM at the time of treatment was retained in the model. The parameter estimate for DIM showed a negative relationship between DIM and LH peak concentration $(-0.003 ; P=$ 0.041). The AUC for cows receiving $200 \mu \mathrm{g}$ of $\mathrm{GnRH}$ was greater $(P<0.001)$ than for cows receiving $100 \mu \mathrm{g}$ of GnRH (Table 2). The model for AUC also indicated a negative relationship $(-0.002 ; P=0.022)$ between DIM and AUC.

For cows in the high-P4 environment, mean LH concentrations were affected by GnRH dose $(P<$ $0.001)$, time $(P<0.001)$, and the GnRH dose by time interaction $(P<0.001$; Figure $3 \mathrm{~A})$. Cows receiving the 100- and 200- $\mu \mathrm{g}$ doses of GnRH had mean LH concentrations less than $10 \mathrm{ng} / \mathrm{mL}$ at all times after $\mathrm{GnRH}$ treatment. Only cows treated with $200 \mu \mathrm{g}$ of $\mathrm{GnRH}$ had mean LH concentrations greater than $5 \mathrm{ng} / \mathrm{mL}$ and only from 1.5 to $2.5 \mathrm{~h}$ after $\mathrm{GnRH}$ treatment when peak LH concentrations occurred. A clear divergence in LH concentrations was observed between the $2 \mathrm{GnRH}$ doses beginning about $1 \mathrm{~h}$ after GnRH treatment, with cows receiving the $100-\mu \mathrm{g}$ dose remaining flat, whereas cows receiving the 200- $\mu \mathrm{g}$ dose having increased LH concentrations. Mean LH concentrations were greater for cows receiving 200 compared with $100 \mu \mathrm{g}$ of $\mathrm{GnRH}$ beginning $1.5 \mathrm{~h}$ until $5 \mathrm{~h}$ after $\mathrm{GnRH}$ treatment, with more than 2-fold greater LH concentrations during this entire period.

The ovulatory response of cows after GnRH treatment in the high-P4 environment was similar $(P=$ $0.306)$ for cows receiving $100 \mu \mathrm{g}(75.0 \%$; 9/12) compared with $200 \mu \mathrm{g}(91.7 \%$; 11/12) of GnRH. For cows treated with $\mathrm{GnRH}$ in the high-P4 environment, the time from $\mathrm{GnRH}$ treatment to ovulation was similar $(P$ $=0.799)$ for cows receiving $100 \mu \mathrm{g}(29.3 \pm 0.5 \mathrm{~h}$; range 28 to $32 \mathrm{~h})$ and $200 \mu \mathrm{g}(29.1 \pm 0.3 \mathrm{~h}$; range 28 to $30 \mathrm{~h})$ of GnRH. The mean diameter of the largest follicle for cows receiving $100 \mu \mathrm{g}$ of $\mathrm{GnRH}$ was $16.9 \mathrm{~mm}$ (range = 14 to $21 \mathrm{~mm}$ ) and was $16.7 \mathrm{~mm}$ (range $=14$ to $20 \mathrm{~mm}$ ) for cows receiving $200 \mu \mathrm{g}$ of $\mathrm{GnRH}$.

For the low-P4 environment (after elimination of the 2 cows that had incomplete luteal regression), $\mathrm{P} 4$ concentrations were similar $(P=0.892)$ for cows receiving 100 or $200 \mu \mathrm{g}$ of $\mathrm{GnRH}$ (Table 2). Cows with low

Table 2. Effect of 100 versus $200 \mu \mathrm{g}$ of GnRH on LH secretion in lactating dairy cows with high or low progesterone concentration ${ }^{1}$

\begin{tabular}{|c|c|c|c|c|c|c|}
\hline Item & \multicolumn{2}{|c|}{ High progesterone } & $P$-value & \multicolumn{2}{|c|}{ Low progesterone } & $P$-value \\
\hline Progesterone (ng/mL) & $\begin{array}{l}3.5 \pm 0.2 \\
\quad(2.2-4.8)\end{array}$ & $\begin{array}{l}3.6 \pm 0.4 \\
\quad(1.1-5.3)\end{array}$ & 0.806 & $\begin{array}{l}0.2 \pm 0.05 \\
\quad(0.1-0.6)\end{array}$ & $\begin{array}{l}0.2 \pm 0.02 \\
\quad(0.1-0.4)\end{array}$ & 0.892 \\
\hline LH peak $(\mathrm{ng} / \mathrm{mL})$ & $3.3 \pm 0.3$ & $8.5 \pm 1.7$ & $<0.001$ & $15.7 \pm 2.2$ & $23.6 \pm 1.6$ & 0.010 \\
\hline Time to LH peak $(\mathrm{h})$ & $1.3 \pm 0.2$ & $1.8 \pm 0.2$ & 0.040 & $1.8 \pm 0.1$ & $1.9 \pm 0.1$ & 0.528 \\
\hline $\mathrm{AUC}^{2}$ (units) & $501.0 \pm 42.6$ & $1,177.8 \pm 193.3$ & $<0.001$ & $2,186.4 \pm 279.7$ & $3,443.2 \pm 198.1$ & 0.002 \\
\hline
\end{tabular}

${ }^{1}$ All values are means \pm SEM; for progesterone, range in parentheses.

${ }^{2}$ Area under the curve. 

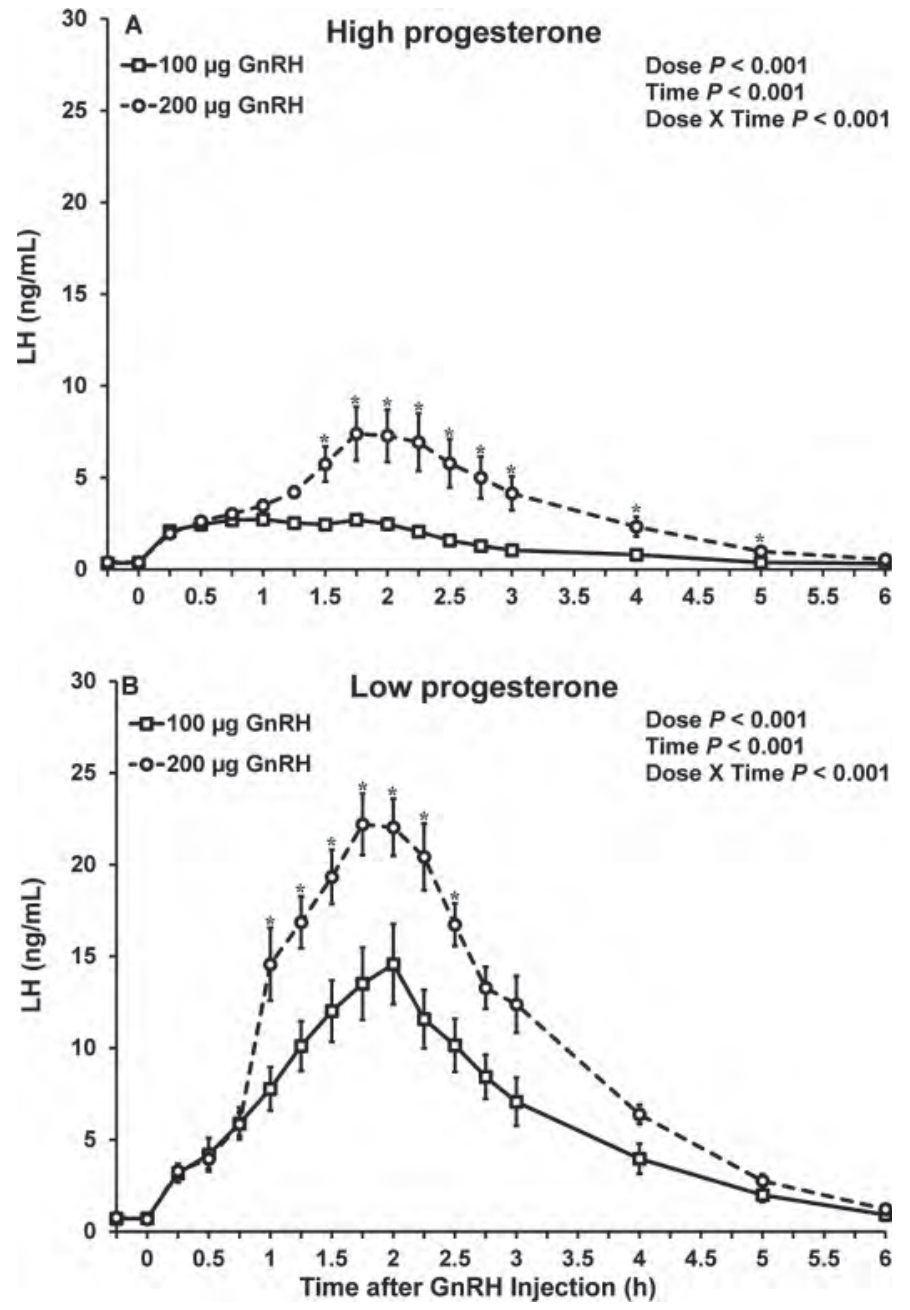

Figure 3. Mean $( \pm \mathrm{SEM})$ LH concentrations for lactating dairy cows in high- [panel A; $100 \mu \mathrm{g}$ of $\mathrm{GnRH}(\mathrm{n}=12)$ and $200 \mu \mathrm{g}$ of $\mathrm{GnRH}$ $(\mathrm{n}=12)$ ] or low- [panel B; $100 \mu \mathrm{g}$ of $\mathrm{GnRH}(\mathrm{n}=12)$ and $200 \mu \mathrm{g}$ of $\mathrm{GnRH}(\mathrm{n}=10)$ ] progesterone $(\mathrm{P} 4)$ environments treated with 100 versus $200 \mu \mathrm{g}$ of GnRH. The high- and low-P4 environments corresponded to the first and second GnRH injections of the Breeding-Ovsynch portion of the Double-Ovsynch protocol, respectively. Asterisks denote a difference (Tukey mean separation test) in mean LH concentration between groups of cows.

P4 that received $200 \mu \mathrm{g}$ of $\mathrm{GnRH}$ had a greater $\mathrm{LH}$ peak than cows receiving $100 \mu \mathrm{g}$ of $\mathrm{GnRH}(P=0.010)$, whereas time to the LH peak was similar $(P=0.528)$ for both groups of cows (Table 2). The AUC for cows receiving $200 \mu \mathrm{g}$ of $\mathrm{GnRH}$ was greater $(P=0.002)$ compared with cows receiving $100 \mu \mathrm{g}$ of GnRH (Table 2).

For cows in the low-P4 environment, mean LH concentrations were affected by GnRH dose $(P<0.001)$, time $(P<0.001)$, and the GnRH dose by time interaction $(P<0.001$; Figure 3B). Unlike the results for the high-P4 environment, the analysis for cows with low $\mathrm{P} 4$ included parity and BCS, but all other covariates in- cluded in the original models were not significant or did not improve model fit and were, therefore, eliminated from all statistical models.

For cows with low P4, both doses of GnRH elicited similar increases in $\mathrm{LH}$ concentrations during the first 45 min of sampling (Figure 3B). Between 45 min and 1 $\mathrm{h}$ after $\mathrm{GnRH}$ treatment, a more dramatic increase in LH concentrations occurred in cows that received 200 $\mu \mathrm{g}$ compared with $100 \mu \mathrm{g}$ of $\mathrm{GnRH}$, although increases in circulating $\mathrm{LH}$ concentrations continued in both groups until about $2 \mathrm{~h}$ after $\mathrm{GnRH}$ treatment. Unlike the high-P4 environment, when neither GnRH dose elicited mean LH concentrations greater than $10 \mathrm{ng} /$ $\mathrm{mL}$, both groups peaked above $10 \mathrm{ng} / \mathrm{mL}$ of circulating $\mathrm{LH}$; however, cows treated with $200 \mu \mathrm{g}$ of $\mathrm{GnRH}$ in a low-P4 environment had an LH peak greater than 20 $\mathrm{ng} / \mathrm{mL}$. Cows in the low-P4 environment treated with $100 \mu \mathrm{g}$ of $\mathrm{GnRH}$ had mean LH concentrations greater than $10 \mathrm{ng} / \mathrm{mL}$ from 1.25 to $2.5 \mathrm{~h}$ after treatment, whereas cows in the low-P4 environment receiving $200 \mu \mathrm{g}$ of $\mathrm{GnRH}$ maintained mean LH concentrations greater than $15 \mathrm{ng} / \mathrm{mL}$ during the same time period. Differences between groups were observed from 1 to 2.5 $\mathrm{h}$ after treatment, with cows receiving $200 \mu \mathrm{g}$ of $\mathrm{GnRH}$ maintaining greater mean LH concentrations than cows receiving $100 \mu \mathrm{g}$ of $\mathrm{GnRH}$.

Ovulatory response to $\mathrm{GnRH}$ treatment for cows in the low-P4 environment was similar $(P=0.979)$ for cows receiving $100 \mu \mathrm{g}(90.9 \%$; 10/11) or $200 \mu \mathrm{g}$ of GnRH $(100.0 \% ; 10 / 10)$. The mean diameter of the largest follicle of cows receiving $100 \mu \mathrm{g}$ of $\mathrm{GnRH}$ was $17.7 \mathrm{~mm}$ (range $=14$ to $24 \mathrm{~mm}$ ), whereas it was 16.0 $\mathrm{mm}$ (range $=12$ to $21 \mathrm{~mm}$ ) for cows receiving $200 \mu \mathrm{g}$ of $\mathrm{GnRH}$. The diameter of the largest follicle of the only low-P4 cow failing to ovulate in response to $\mathrm{GnRH}$ was $16 \mathrm{~mm}$. For cows in the low-P4 environment, the time from $\mathrm{GnRH}$ treatment to ovulation was similar $(P=$ $0.686)$ for cows receiving $100 \mu \mathrm{g}(28.6 \pm 0.3 \mathrm{~h}$, range 28 to $30 \mathrm{~h})$ compared with $200 \mu \mathrm{g}(28.8 \pm 0.3 \mathrm{~h}$, range 28 to $30 \mathrm{~h}$ ) of GnRH.

\section{Individual Cow LH Responses to GnRH by P4 Concentration}

Figure 4 shows the relationship between $\mathrm{P} 4$ and AUC (panel A) and peak LH (panel B) concentration for individual cows after the 2 doses of GnRH. For both AUC and LH peak, it is possible to distinguish clear patterns due to dose of GnRH, but particularly due to P4 concentration. In general, cows with $\mathrm{P} 4$ concentrations greater than $1 \mathrm{ng} / \mathrm{mL}$ had low total LH secretion (AUC $<1,000$ units) and LH peak $[78 \%(18 / 23)$ peaked below $5 \mathrm{ng} / \mathrm{mL}$ ] compared with cows with lower P4 concentrations. Most cows with $\mathrm{P} 4>1.0 \mathrm{ng} / \mathrm{mL}$ receiving 

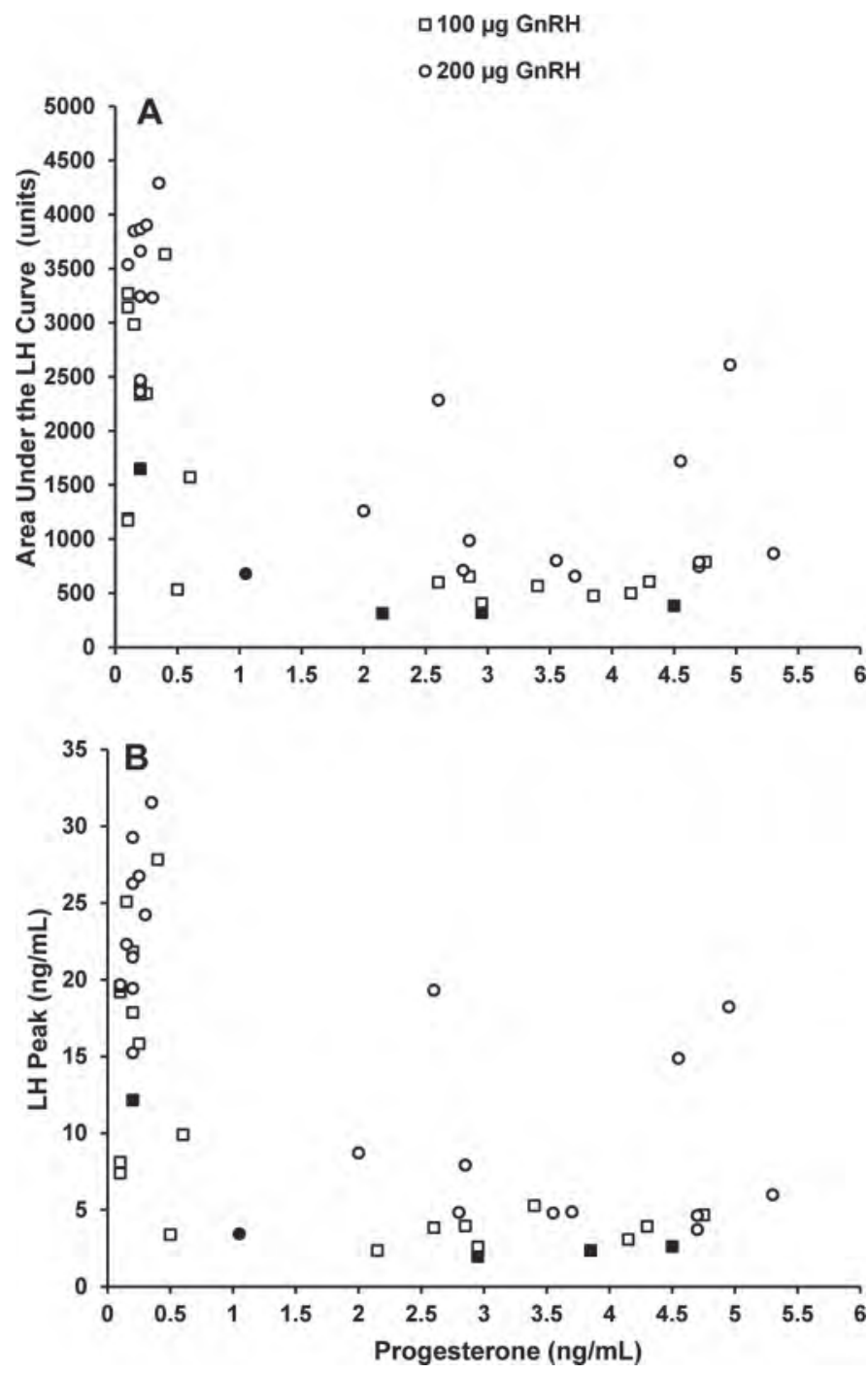

Figure 4. Relationship between progesterone concentration at GnRH treatment, area under the curve (AUC; arbitrary units; panel A), and peak LH concentration (panel B) in lactating dairy cows. Filled squares and circles denote individual cows that failed to ovulate in response to $\mathrm{GnRH}$ treatment.

$200 \mu \mathrm{g}$ of GnRH had LH concentrations only slightly greater than cows receiving $100 \mu \mathrm{g}$ of $\mathrm{GnRH}$, except for a few cows that had dramatically greater LH responses than the rest of the cows. One cow receiving $200 \mu \mathrm{g}$ of GnRH and having $\mathrm{P} 4$ concentration slightly greater than $1 \mathrm{ng} / \mathrm{mL}$ had an $\mathrm{LH}$ response similar to that of cows with much greater circulating $\mathrm{P} 4$ concentrations.

On the other hand, most cows with $\mathrm{P} 4$ concentration less than $1 \mathrm{ng} / \mathrm{mL}$ had dramatically greater $\mathrm{LH}$ responses and, in general, more variation than cows with high $\mathrm{P} 4$ concentrations. In this case, the greatest variation in LH response was observed for cows receiving $100 \mu \mathrm{g}$ of $\mathrm{GnRH}$. Indeed, although most cows had LH responses similar to that of cows receiving 200 $\mu \mathrm{g}$ of $\mathrm{GnRH}$ in the low-P4 environment, a few low-P4 cows receiving $100 \mu \mathrm{g}$ of $\mathrm{GnRH}$ had much lower LH responses. Except for 1 low-P4 cow that failed to ovulate and had an AUC of 1,650 units and an LH peak of 12 $\mathrm{ng} / \mathrm{mL}$, most cows failing to ovulate had an LH surge of low magnitude with AUC of less than 700 units and an LH peak less than $5 \mathrm{ng} / \mathrm{mL}$ (Figure 4).

\section{DISCUSSION}

This experiment was designed to evaluate the effect of circulating $\mathrm{P} 4$ on response to 2 different doses of GnRH observed during protocols used to synchronize ovulation for TAI in lactating dairy cows. Therefore, we chose to evaluate the magnitude of LH response to GnRH at a time when P4 was elevated, such that occurs in cows at the first GnRH injection of the Ovsynch protocol, compared with the $\mathrm{GnRH}$ response at a time when $\mathrm{P} 4$ was low, such that occurs in cows at the time of the second GnRH injection of the Ovsynch protocol. The most important observation in this experiment was the consistently lower response to GnRH when cows were in a high-P4 environment, supporting our first hypothesis that $\mathrm{P} 4$ concentrations affect the magnitude of a GnRH-induced LH surge. With either dose of GnRH, a 3 to 5 -fold increase in the peak of the LH surge or AUC for LH occurred when cows were treated with $\mathrm{GnRH}$ in the low- compared with the high-P4 environment. Our second hypothesis, that increasing the dose of $\mathrm{GnRH}$ would increase the magnitude of the LH surge regardless of $\mathrm{P} 4$ environment, was also supported by our results. Our results provide a better understanding of key physiology related to practical reproductive management programs that use $\mathrm{GnRH}$ for synchronization of ovulation and have important biological and practical implications for future reproductive research.

Cows treated with GnRH in the high-P4 environment had average P4 concentrations greater than $3 \mathrm{ng} / \mathrm{mL}$, similar to P4 concentrations in many cows $7 \mathrm{~d}$ after an induced ovulation. Such physiological conditions are usually observed in cows presynchronized with protocols like Double-Ovsynch (Souza et al., 2008; Giordano et al., 2012) and Presynch-Ovsynch (Moreira et al., 2001). Moreover, this high-P4 environment occurs in cycling cows that start the Ovsynch protocol in the presence of a functional CL (Stevenson et al., 1999; Bello et al., 2006; Giordano et al., 2012). By contrast, cows treated with $\mathrm{GnRH}$ in a low-P4 environment had circulating $\mathrm{P} 4$ of only $0.2 \mathrm{ng} / \mathrm{mL}$, similar to concentrations in cows with complete luteal regression in response to a luteolytic dose of $\mathrm{PGF}_{2 \alpha}$ (Brusveen et al., 2009; Giordano et al., 2012). All cows with $\mathrm{P} 4$ concentrations less than $0.5 \mathrm{ng} / \mathrm{mL}$ had an LH peak greater than $5 \mathrm{ng} / \mathrm{mL}$ and almost all cows with low P4 (86\%) had an LH peak 
greater than $10 \mathrm{ng} / \mathrm{mL}$. By contrast, only $13 \%$ of cows with $\mathrm{P} 4$ greater than $1 \mathrm{ng} / \mathrm{mL}$ had an LH peak greater than $10 \mathrm{ng} / \mathrm{mL}$ with the average LH peak of only 3.3 $\mathrm{ng} / \mathrm{mL}$ for cows receiving $100 \mu \mathrm{g}$ of GnRH and $8.5 \mathrm{ng} /$ $\mathrm{mL}$ for cows receiving $200 \mu \mathrm{g}$ of $\mathrm{GnRH}$. Attenuation of the $\mathrm{GnRH}$-induced LH surge in a high-P4 environment has been reported in beef heifers and cows (Cline, 2002; Colazo et al., 2008; Dias et al., 2010). Moreover, a similar suppressive effect of $\mathrm{P} 4$ on $\mathrm{LH}$ secretion has been reported for cattle receiving a GnRH injection during the luteal phase of the estrous cycle compared with cows treated during metestrus or proestrus (Schams et al., 1974; Atkins et al., 2008). The mechanisms that underlie the decrease in GnRH-induced LH secretion have not yet been fully elucidated.

The gonadal steroids E2 and P4 are key regulators of gonadotropin secretion in cattle (Nett et al., 2002; Clarke and Pompolo, 2005; Rispoli and Nett, 2005). This can occur through regulation of the hypothalamus by altering frequency or amplitude of $\mathrm{GnRH}$ pulses as well as by direct regulation of $\mathrm{GnRH}$ responsiveness at the anterior pituitary (Goodman and Karsch, 1980; Schoenemann et al., 1985; Nett et al., 2002). In the present study, we observed a decreased responsiveness of the pituitary gland to exogenous $\mathrm{GnRH}$ treatment in the presence of high circulating concentrations of P4. During the follicular phase of the estrous cycle, the absence of $\mathrm{P} 4$ and the presence of increased E2 and GnRH pulses stimulates expression of GnRH receptor mRNA in pituitary cells (Turzillo and Nett, 1995). The subsequent increase in GnRH receptors on the cell membrane of gonadotrophs allows for a robust preovulatory $\mathrm{LH}$ surge in response to the preovulatory $\mathrm{GnRH}$ surge (Schoenemann et al., 1985; Turzillo and Nett, 1995; Turzillo et al., 1998). This scenario likely corresponds to the low-P4 environment in our experiment. Conversely, during the luteal phase of the estrous cycle when circulating $\mathrm{P} 4$ concentrations are high, the number of GnRH receptors on the pituitary cells are decreased either due to direct suppressive effects of $\mathrm{P} 4$ or lack of stimulatory effects of $\mathrm{E} 2$ on pituitary GnRH receptor numbers (Turzillo et al., 1998; Rispoli and Nett, 2005). Our experimental design does not allow us to separate the effects of changes in E2 from the effects of P4. It is tempting to speculate that the decrease in GnRHinduced LH release is due to a decrease in pituitary GnRH receptors because fewer receptors are present during the luteal phase (Rispoli and Nett, 2005) and an association exists between the amplitude of LH pulses after exogenous $\mathrm{GnRH}$ and pituitary $\mathrm{GnRH}$ receptors (Wise et al., 1984). Nevertheless, we are not able to distinguish whether the decreased GnRH-induced LH surge is due to decreased numbers of GnRH receptors or a decreased responsiveness within pituitary cells to activation of $\mathrm{GnRH}$ receptors (i.e., decreased activation of second messengers). Another possibility is that a decreased quantity of releasable LH in the pituitary of cows exists in the high-P4 environment; however, previous studies have not found decreased pituitary LH content after P4 treatment (Moss et al., 1981; Baratta et al., 1994). In addition, our observation that a doubling of the GnRH dose caused a concomitant doubling in LH release indicates that more releasable $\mathrm{LH}$ was present than was released when cows were treated with $100 \mu \mathrm{g}$ of GnRH in either the high-P4 or low-P4 environment.

Besides ovarian steroids, GnRH itself plays an important role in the regulation of its own receptor with greater $\mathrm{GnRH}$ release upregulating the $\mathrm{GnRH}$ receptor in the pituitary (Nett et al., 2002). Thus, inhibition of $\mathrm{GnRH}$ pulses by $\mathrm{P} 4$ might decrease the number of $\mathrm{GnRH}$ receptors and, therefore, the responsiveness of pituitary cells through this indirect pathway. Interestingly, one experiment in sheep concluded that the suppressive effect of $\mathrm{P} 4$ on $\mathrm{LH}$ release was not related to number of GnRH receptors (Girmus et al., 1996). Actions of $\mathrm{P} 4$ directly on the pituitary are clearly possible because receptors for $\mathrm{P} 4$ are present in the ovine (Girmus et al., 1996) and bovine (Jacobs and Smith, 1981; Baratta et al., 1994) anterior pituitary and may mediate the direct effects of $\mathrm{P} 4$ on LH release (Batra and Miller, 1985; Girmus and Wise, 1992). Furthermore, acute actions of $\mathrm{P} 4$ on the anterior pituitary may involve membrane-bound nongenomic receptors for P4 (Ashley et al., 2006; Ashley et al., 2009) rather than classical P4 receptors, which act as transcription factors.

There are many practical implications of the suppression of a GnRH-induced LH surge. As previously mentioned, the physiological conditions of the high-P4 environment, with consequent suppression of ovulation, are usually observed in lactating dairy cows that are either presynchronized or initiate the Ovsynch protocol during diestrus (Stevenson et al., 2008; Galvão and Santos, 2010; Giordano et al., 2012). Ovulation after $\mathrm{GnRH}$ treatment is necessary to ensure the initiation of a new follicular wave to maximize the chances of a synchronized ovulation around the TAI. Moreover, some studies have reported a decreased ovulatory response to GnRH in cows receiving an intravaginal progesterone releasing (CIDR) insert at $\mathrm{GnRH}$ administration (Galvão et al., 2004; Stevenson et al., 2008). In lactating dairy cows receiving a CIDR device, circulating P4 concentrations increased within 15 min after treatment with a new or used CIDR insert (Cerri et al., 2009). Thus, we speculate that in addition to the long-term effect (days) of P4 to suppress ovulation, an acute effect of $\mathrm{P} 4$ is also possibly mediated through an acute sup- 
pression of GnRH-induced LH secretion. In addition, previous difficulties in inducing ovulation with $\mathrm{GnRH}$ in cows with a functional CL, such as pregnant cows or nonlactating heifers (unpublished observations), even in the presence of growing dominant follicles, may be related to decreased GnRH-induced LH secretion rather than the inability of follicles to ovulate.

The second hypothesis of this experiment was that an increased GnRH dose would increase LH secretion. Increasing the GnRH dose from 100 to $200 \mu \mathrm{g}$ increased both the peak of the LH surge and the AUC. In addition, LH dynamics differed according to the dose of GnRH with no clear peak in LH for cows receiving 100 $\mu \mathrm{g}$ of $\mathrm{GnRH}$ in a high-P4 environment, whereas cows receiving $200 \mu \mathrm{g}$ of $\mathrm{GnRH}$ produced a clear LH peak, even in a high-P4 environment. These observations in the high-P4 environment indicate that the greater dose of GnRH partially overcame the suppressive effect of circulating $\mathrm{P} 4$ on $\mathrm{GnRH}$-induced LH release.

For cows in the low-P4 environment, both doses of GnRH induced a major LH surge with only 1 cow having a LH peak less than $5 \mathrm{ng} / \mathrm{mL}$ and AUC less than a 1,000 units. Overall, treatment with $200 \mu \mathrm{g}$ of $\mathrm{GnRH}$ enhanced LH secretion, resulting in greater LH peak, mean LH, and total LH secreted (AUC) compared with cows receiving $100 \mu \mathrm{g}$ of GnRH. The total amount of LH released after GnRH was 1.6 times greater in cows treated with 100 compared with $200 \mu \mathrm{g}$ of GnRH.

In contrast with these results, Chenault et al. (1990) reported no differences in serum LH concentration after increasing the dose of gonadorelin from 100 to $250 \mu \mathrm{g}$ in Holstein heifers with concentrations of $\mathrm{P} 4$ characteristic of mid to late diestrus ( $\mathrm{d} 8$ to 16 of the estrous cycle). In the latter study, AUC and peak LH concentration were numerically greater for heifers treated with the higher GnRH dose; however, the difference did not reach statistical significance. In the same study, a difference in total LH secretion was only detected when heifers were treated with $500 \mu \mathrm{g}$ of gonadorelin, supporting the notion that greater $\mathrm{GnRH}$ doses generate greater $\mathrm{LH}$ responses. The discrepancies between the present study and that of Chenault et al. (1990) regarding LH secretion in response to 100 versus $250 \mu \mathrm{g}$ of $\mathrm{GnRH}$ may be partially due to the desensitization of the pituitary reported for some of the doses and analogs used. The 48-h interval between GnRH injections in Chenault et al. (1990) may have precluded a full pituitary response to $\mathrm{GnRH}$ in heifers previously receiving a desensitizing dose of some of the GnRH analogs. It is also intriguing that a lack of difference was observed in LH secretion in Holstein heifers receiving 100 compared with $500 \mu \mathrm{g}$ of gonadorelin $24 \mathrm{~h}$ after a luteolytic dose of a synthetic $\mathrm{PGF}_{2 \alpha}$ analog (Rantala et al., 2009). Conversely, in agreement with our results, Dias et al. (2010) reported that beef heifers treated with $200 \mu \mathrm{g}$ of gonadorelin when mean $\mathrm{P} 4$ concentration was 6 to $7 \mathrm{ng} / \mathrm{mL}$ had greater mean LH concentration at 1 and $2 \mathrm{~h}$ after treatment than heifers receiving $100 \mu \mathrm{g}$ of GnRH. Dias et al. (2010) also reported greater mean LH concentration in a lower-P4 environment when comparing the same GnRH doses as in the present study. Our results are also in partial agreement with those reported by Colazo et al. (2009) for ovariectomized nonlactating Holstein cows treated with 50,100 , or $250 \mu \mathrm{g}$ of gonadorelin after an induced follicular phase. Cows receiving the highest GnRH dose had greater mean LH concentrations and duration of the LH surge but not a greater LH peak when compared with cows receiving the lower GnRH doses.

Taken together, results of these previous studies and the current experiment suggest that increasing the GnRH dose from 100 to $200 \mu \mathrm{g}$ may be a practical method for increasing GnRH-induced LH secretion in lactating dairy cows in a high-P4 environment. Clearly, the LH surge in response to the recommended $\mathrm{GnRH}$ dose of $100 \mu \mathrm{g}$ for cattle is attenuated by $\mathrm{P} 4$ and it seems likely that some cows will have an insufficient LH surge to induce ovulation. This may be particularly important to maximize ovulatory response to the first GnRH injection of Ovsynch in protocols that include presynchronization of ovulation before initiation of the Ovsynch protocol either for first service (Moreira et al., 2001; Bello et al., 2006; Souza et al., 2008) or for cows resynchronized for second and subsequent AI services (Dewey et al., 2010; Giordano et al., 2012). Likewise, the 200- $\mu \mathrm{g}$ dose of GnRH may be used to increase the release of pituitary LH in a low-P4 environment. In this case, however, an LH peak of greater magnitude may not be as critical as under a high-P4 environment given the acceptable LH surges observed for cows treated with $100 \mu \mathrm{g}$ of $\mathrm{GnRH}$.

Despite the dramatic differences in LH secretion in the high- and low-P4 environment for cows treated with 100 and $200 \mu \mathrm{g}$ of $\mathrm{GnRH}$, no differences were observed for ovulatory response. Overall, ovulatory response in this study was high, which could be explained, at least in part, because cows were selected throughout the presynchronization part of the protocol and only those cows that responded adequately to the previous injections, had a functional CL, and a follicle of ovulatory size remained in the experiment. In addition, the number of cows used in this study may have precluded the detection of statistical differences regardless of some clear trends in ovulatory response. In general, more cows treated with $200 \mu \mathrm{g}$ of $\mathrm{GnRH}$ ovulated both in the high- and the low-P4 environment. Interestingly, a similar percentage of cows ovulated to the $200-\mu \mathrm{g}$ dose of GnRH in the high-P4 environment than cows 
treated with the 100- $\mu \mathrm{g}$ dose in the low-P4 environment. As expected, the lowest ovulatory response was observed for cows treated with $100 \mu \mathrm{g}$ of $\mathrm{GnRH}$ in the high-P4 environment because they had an LH surge of low magnitude. Indeed, most cows (3 out of 5) that failed to ovulate in this experiment received the low dose of GnRH in the high-P4 environment and had some of the lowest LH responses with low AUC and LH surge peaks. The fourth cow that failed to ovulate in the high-P4 environment received the 200- $\mu$ g dose of GnRH but the magnitude of the LH surge was comparable to that of cows receiving $100 \mu \mathrm{g}$ of $\mathrm{GnRH}$ in the high-P4 environment.

\section{CONCLUSIONS}

Results from the present experiment indicate that $\mathrm{P} 4$ concentrations at GnRH treatment dramatically suppress GnRH-induced LH release in lactating dairy cows receiving 100 or $200 \mu \mathrm{g}$ of GnRH. Cows receiving either dose of $\mathrm{GnRH}$ in the high-P4 environment had an $\mathrm{LH}$ surge of much lower magnitude than cows treated with the same doses of GnRH in the low-P4 environment. In addition, treatment with $200 \mu \mathrm{g}$ of GnRH enhanced pituitary LH release when compared with the recommended dose of $100 \mu \mathrm{g}$ of $\mathrm{GnRH}$ for cattle both in the high- and the low-P4 environment.

\section{ACKNOWLEDGMENTS}

The authors thank the University of Wisconsin dairy herd personnel at the Blaine Dairy Cattle Center (Arlington, WI) and the Dairy Cattle Center (Madison, WI) for their help with data collection and cow handling during the course of this experiment. Appreciation is also extended to M. A. Beg from the Department of Biomedical Science at the School of Veterinary Medicine of the University of Wisconsin-Madison for help with the LH assay. This research was supported by the Wisconsin Experiment Station and Hatch project WIS01171 to P. M. Fricke.

\section{REFERENCES}

Ashley, R. L., J. A. Arreguin-Arevalo, and T. M. Nett. 2009. Binding characteristics of the ovine membrane progesterone receptor alpha and expression of the receptor during the estrous cycle. Reprod. Biol. Endocrinol. 7:42.

Ashley, R. L., C. M. Clay, T. A. Farmerie, G. D. Niswender, and T. M. Nett. 2006. Cloning and characterization of an ovine intracellular seven transmembrane receptor for progesterone that mediates calcium mobilization. Endocrinology 147:4151-4159.

Atkins, J. A., D. C. Busch, J. F. Bader, D. H. Keisler, D. J. Patterson, M. C. Lucy, and M. F. Smith. 2008. Gonadotropin-releasing hormone-induced ovulation and luteinizing hormone release in beef heifers: Effect of day of the cycle. J. Anim. Sci. 86:83-93.
Baratta, M., F. Grasselli, and C. Tamanini. 1994. Effects of gonadal steroids on tonic luteinizing hormone ( $\mathrm{LH})$ release and luteinizing hormone-releasing hormone-induced LH release from bovine pituitary cells cultured in vitro. Biol. Reprod. 50:1320-1327.

Batra, S. K., and W. L. Miller. 1985. Progesterone decreases the responsiveness of ovine pituitary cultures to luteinizing hormonereleasing hormone. Endocrinology 117:1436-1440.

Bello, N. M., J. P. Steibel, and J. R. Pursley. 2006. Optimizing ovulation to first GnRH improved outcomes to each hormonal injection of Ovsynch in lactating dairy cows. J. Dairy Sci. 89:3413-3424.

Brusveen, D. J., A. H. Souza, and M. C. Wiltbank. 2009. Effects of additional $\mathrm{PGF}_{2 \alpha}$ and estradiol-17 $\beta$ during Ovsynch in lactating dairy cows. J. Dairy Sci. 92:1412-1422.

Caraviello, D. Z., K. A. Weigel, P. M. Fricke, M. C. Wiltbank, M. J. Florent, N. B. Cook, K. V. Nordlund, N. R. Zwald, and C. L. Rawson. 2006. Survey of management practices on reproductive performance of dairy cattle on large US commercial farms. J. Dairy Sci. 89:4723-4735.

Cerri, R. L., H. M. Rutigliano, R. G. Bruno, and J. E. Santos. 2009. Progesterone concentration, follicular development and induction of cyclicity in dairy cows receiving intravaginal progesterone inserts. Anim. Reprod. Sci. 110:56-70.

Chebel, R. C., J. E. Santos, R. L. Cerri, H. M. Rutigliano, and R. G. Bruno. 2006. Reproduction in dairy cows following progesterone insert presynchronization and resynchronization protocols. J. Dairy Sci. 89:4205-4219.

Chenault, J. R., D. D. Kratzer, R. A. Rzepkowski, and M. C. Goodwin. 1990. LH and FSH response of Holstein heifers to fertirelin acetate, gonadorelin and buserelin. Theriogenology 34:81-98.

Clarke, I. J., and S. Pompolo. 2005. Synthesis and secretion of GnRH. Anim. Reprod. Sci. 88:29-55.

Cline, M. A. 2002. Efficacy of synthetic gonadotropin releasing hormone analogs for control of ovulation during estrus synchronization protocols. MS Thesis. Virginia Polytechnic Institute in Animal Science, Blacksburg, VA.

Colazo, M. G., J. P. Kastelic, H. Davis, M. D. Rutledge, M. F. Martinez, J. A. Small, and R. J. Mapletoft. 2008. Effects of plasma progesterone concentrations on LH release and ovulation in beef cattle given GnRH. Domest. Anim. Endocrinol. 34:109-117.

Colazo, M. G., T. O. Ree, D. G. Emmanuel, and D. J. Ambrose. 2009. Plasma luteinizing hormone concentrations in cows given repeated treatments or three different doses of gonadotropin releasing hormone. Theriogenology 71:984-992.

Dewey, S. T., L. G. D. Mendonça, G. Lopes Jr., F. A. Rivera, F. Guagnini, R. C. Chebel, and T. R. Bilby. 2010. Resynchronization strategies to improve fertility in lactating dairy cows utilizing a presynchronization injection of GnRH or supplemental progesterone: I. Pregnancy rates and ovarian responses. J. Dairy Sci. 93:4086-4095.

Dias, F. C., M. G. Colazo, J. P. Kastelic, R. J. Mapletoft, G. P. Adams, and J. Singh. 2010. Progesterone concentration, estradiol pretreatment, and dose of gonadotropin-releasing hormone affect gonadotropin-releasing hormone-mediated luteinizing hormone release in beef heifers. Domest. Anim. Endocrinol. 39:155-162.

Galvão, K. N., and J. E. P. Santos. 2010. Factors affecting synchronization and conception rate after the Ovsynch protocol in lactating Holstein cows. Reprod. Domest. Anim. 45:439-446.

Galvão, K. N., J. E. P. Santos, S. O. Juchem, R. L. A. Cerri, A. C. Coscioni, and M. Villaseñor. 2004. Effect of addition of a progesterone intravaginal insert to a timed insemination protocol using estradiol cypionate on ovulation rate, pregnancy rate, and late embryonic loss in lactating dairy cows. J. Anim. Sci. 82:3508-3517.

Giordano, J. O., M. C. Wiltbank, J. N. Guenther, R. Pawlisch, S. Bas, A. P. Cunha, and P. M. Fricke. 2012. Increased fertility in lactating dairy cows resynchronized with Double-Ovsynch compared with Ovsynch initiated $32 \mathrm{~d}$ after timed artificial insemination. J. Dairy Sci. 95:639-653.

Girmus, R. L., A. M. Dunn, T. M. Nett, E. Esquivel, and M. E. Wise. 1996. Estradiol up-regulation of pituitary progesterone binding is required for progesterone inhibition of luteinizing hormone release. Endocrine 4:53-58. 
Girmus, R. L., and M. E. Wise. 1992. Progesterone directly inhibits pituitary luteinizing hormone secretion in an estradiol-dependent manner. Biol. Reprod. 46:710-714.

Goodman, R. L., and F. J. Karsch. 1980. Pulsatile secretion of luteinizing hormone: Differential suppression by ovarian steroids. Endocrinology 107:1286-1290.

Hannan, M. A., M. J. Fuenzalida, M. A. R. Siddiqui, M. Shamsuddin, M. A. Beg, and O. J. Ginther. 2010. Diurnal variation in LH and temporal relationships between oscillations in LH and progesterone during the luteal phase in heifers. Theriogenology 74:1491-1498.

Jacobs, B. R., and R. G. Smith. 1981. A comparison of progesterone and R5020 binding in endometrium, ovary, pituitary, and hypothalamus. Fertil. Steril. 35:438-441.

Keskin, A., G. Yilmazbas-Mecitoglu, E. Karakaya, A. Alkan, H. Okut, A. Gumen, and M.C. Wiltbank. 2011. Effect of presynchronization strategy prior to Ovsynch on fertility at first service in lactating dairy cows. J. Dairy Sci. 94(E-Suppl. 1):191

Moreira, F., C. Orlandi, C. A. Risco, R. Mattos, F. Lopes, and W. W. Thatcher. 2001. Effects of presynchronization and bovine somatotropin on pregnancy rates to a timed artificial insemination protocol in lactating dairy cows. J. Dairy Sci. 84:1646-1659.

Moss, G. E., M. E. Crowder, and T. M. Nett. 1981. GnRH-receptor interaction. VI. Effect of progesterone and estradiol on hypophyseal receptors for $\mathrm{GnRH}$, and serum and hypophyseal concentrations of gonadotropins in ovariectomized ewes. Biol. Reprod. 25:938-944.

NRC. 2001. Nutrient Requirements of Dairy Cattle. 7th ed. Natl. Acad. Sci., Washington, DC

Nett, T. M., A. M. Turzillo, M. Baratta, and L. A. Rispoli. 2002. Pituitary effects of steroid hormones on secretion of follicle-stimulating hormone and luteinizing hormone. Domest. Anim. Endocrinol. $23: 33-42$.

Norman, H. D., J. R. Wright, S. M. Hubbard, R. H. Miller, and J. L. Hutchison. 2009. Reproductive status of Holstein and Jersey cows in the United States. J. Dairy Sci. 92:3517-3528.

Olynk, N. J., and C. A. Wolf. 2008. Economic analysis of reproductive management strategies on US commercial dairy farms. J. Dairy Sci. 91:4082-4091.

Palhao, M. P., M. A. Beg, M. T. Rodrigues, and O. J. Ginther. 2009. Follicle and hormone dynamics in single versus double ovulating heifers. Reproduction 138:561-570.

Pursley, J. R., M. O. Mee, and M. C. Wiltbank. 1995. Synchronization of ovulation in dairy cows using $\mathrm{PGF}_{2 \alpha}$ and $\mathrm{GnRH}$. Theriogenology 44:915-923.

Rantala, M. H., O. A. T. Peltoniemi, T. Katila, and J. Taponen. 2009. Effect of GnRH dose on occurrence of short oestrous cycles and LH response in cyclic dairy heifers. Reprod. Domest. Anim. 44:647-652.

Rispoli, L. A., and T. M. Nett. 2005. Pituitary gonadotropin-releasing hormone $(\mathrm{GnRH})$ receptor: Structure, distribution and regulation of expression. Anim. Reprod. Sci. 88:57-74.
Schams, D., F. Höfer, E. Schallenberger, M. Hartl, and H. Karg. 1974. Pattern of luteinizing hormone (LH) and follicle stimulating hormone (FSH) in bovine blood plasma after injection of a synthetic gonadotropin-releasing hormone (Gn-RH). Theriogenology 1:137-151.

Schoenemann, H. M., W. D. Humphrey, M. E. Crowder, T. M. Nett, and J. J. Reeves. 1985. Pituitary luteinizing hormone-releasing hormone receptors in ovariectomized cows after challenge with ovarian steroids. Biol. Reprod. 32:574-583.

Souza, A. H., H. Ayres, R. M. Ferreira, and M. C. Wiltbank. 2008. A new presynchronization system (Double-Ovsynch) increases fertility at first postpartum timed AI in lactating dairy cows. Theriogenology 70:208-215.

Souza, A. H., A. P. Cunha, E. P. B. Silva, A. Gümen, H. Ayres, J. N. Guenther, and M. C. Wiltbank. 2009. Comparison of gonadorelin products in lactating dairy cows: Efficacy based on induction of ovulation of an accessory follicle and circulating luteinizing hormone profiles. Theriogenology 72:271-279.

Stevenson, J. S., Y. Kobayashi, and K. E. Thompson. 1999. Reproductive performance of dairy cows in various programmed breeding systems including OvSynch and combinations of gonadotropinreleasing hormone and $\mathrm{PGF}_{2 \alpha}$. J. Dairy Sci. 82:506-515.

Stevenson, J. S., D. E. Tenhouse, R. L. Krisher, G. C. Lamb, J. E. Larson, C. R. Dahlen, J. R. Pursley, N. M. Bello, P. M. Fricke, M. C. Wiltbank, D. J. Brusveen, M. Burkhart, R. S. Youngquist, and H. A. Garverick. 2008. Detection of anovulation by heatmount detectors and transrectal ultrasonography before treatment with progesterone in a timed insemination protocol. J. Dairy Sci. 91:2901-2915.

Turzillo, A. M., J. A. Clapper, G. E. Moss, and T. M. Nett. 1998. Regulation of ovine GnRH receptor gene expression by progesterone and oestradiol. J. Reprod. Fertil. 113:251-256.

Turzillo, A. M., and T. M. Nett. 1995. Effects of estradiol on concentrations of gonadotropin-releasing hormone receptor messenger ribonucleic acid following removal of progesterone. Endocrine 3:765-768

Wise, M. E., D. Nieman, J. Stewart, and T. M. Nett. 1984. Effect of number of receptors for gonadotropin-releasing hormone on the release of luteinizing hormone. Biol. Reprod. 31:1007-1013.

Yamada, K., T. Nakao, K. Nakada, and G. Matsuda. 2002. Influence of $\mathrm{GnRH}$ analogue (fertirelin acetate) doses on synchronization of ovulation and fixed-time artificial insemination in lactating dairy cows. Anim. Reprod. Sci. 74:27-34.

Zolman, J., E. M. Convey, and J. H. Britt. 1974. Relationships between the luteinizing hormone response to gonadotropin releasing hormone and endogenous steroids. J. Anim. Sci. 39:355-359. 